responsibilities of a trauma surgeon are not limited to the mechanical repair of the various injuries, but include physiological support of the patient, organization of the team and hospital resources, coordination of pre-hospital care, research and education.

Harlem Hospital Center was established in 1887, serving a population that is depressed. People in the area are poor and deprived and suffer from severe illnesses and an extraordinary high number of interpersonal injuries. Starting as a 20 bed hospital 100 years ago, it has grown into a relatively modern $\mathbf{8 0 0}$ bed institution. Its experience in trauma management has been unique. It has contributed a great deal to the management of various trauma which has brought this center into international focus. This also led to the development of an organized trauma service as a separate surgical division and was later designated as one of the four certified centers for the treatment of trauma in New York City. Our overall experience over the past five years in trauma management, as well as special types of injuries encountered and their management, will be presented. Planning, teaching and organization of a trauma service will also be discussed so as to share the information and experience with others whose population and type of injuries are similar to ours.

\section{PATTERNS OF DYING FROM SEVERE BLOOD LOSS IN AWAKE RATS}

\author{
David Crippen, M.D., Peter Safar, M.D. and \\ Catherine Snyder, Pittsburgh, \\ Pennsylvania, U.S.A.
}

The RRC has established volume controlled hemorrhagic models in awake rats (McGlew et al, Circ Shock 16:35, 1985) and lightly anesthetized monkeys (Bar-Joseph et al, JWAEDM 1, SI:169, 1985). In this study, we determined in awake spontaneously breathing rats, responses and dying patterns in the same model over $3 \mathrm{~h}$ post-hemorrhage $(\mathrm{H})$, while monitoring art. and $\mathrm{CV}$ pressures, breathing movements, EEG, and art. blood gases. Four groups of 10 rats each were studied. After cannulation under light anesthesia, and awakening, the rats were bled over 20 min: Gr I, $2 \mathrm{ml} / 100 \mathrm{~g} \mathrm{H}$; Gr II, $2.5 \mathrm{ml} / 100 \mathrm{~g} \mathrm{H}$; $\mathrm{Gr}$ III, $3 \mathrm{ml} / 100 \mathrm{~g} \mathrm{H}$; Gr IV , $3.5 \mathrm{ml} / 100 \mathrm{~g} \mathrm{H}$. Death was defined as syst. $\mathrm{BP} \geq 25 \mathrm{mmHg}$. Results: Survival rates were $90 \%$ after $\mathrm{H} 2 \mathrm{ml} / 100 \mathrm{~g} ; 80 \%$ after $\mathrm{H} 2.5$ $\mathrm{ml} / 100 \mathrm{~g} ; 40 \%$ after $\mathrm{H} 3 \mathrm{ml} / 100 \mathrm{~g}$ with mean survival time 73 (7-162) $\mathrm{min}$; and $0 \%$ after $\mathrm{H} 3.5 \mathrm{ml} / 100$ $\mathrm{g}$ with mean survival time 32 (1-122) min. Art. press. decreased at end of $\mathrm{H}$ to a minimum of $30 \mathrm{mmHg}$, rose transiently in all groups (attempted self-resuscitation), and then either recovered to near normotension or declined to death. Art. $\mathrm{PO}_{2}$ increased. Art. $\mathrm{PCO}_{2}, \mathrm{pH}$, Hct decreased. Hyperventilation changed to gasping until pulselessness. EEG depression correlated with hypotension. Conclusions: The $\mathrm{H} 3.5$ $\mathrm{ml} / 100 \mathrm{~g}$ model is suitable (and will be used next) for the study of responses to field resuscitation potentials suitable for use by laymen, with the aim to delay secondary cardiac arrest from severe hemorrhage while waiting for transport (e.g., external stimuli, rectal fluids, hypothermia, $\mathrm{O}_{2}$ inhalation). (Assisted by Lisa Porter. Supported by A.S. Laerdal Foundation.)

\section{EFFECTS OF SODIUM BICARBONATE IN CANINE HEMORRHAGIC SHOCK}

\author{
Thomas J. Iberti, M.D., New York, \\ New York, U.S.A.
}

We studied the use of sodium bicarbonate $\left(\mathrm{NaHCO}_{3}\right)$ administration in a canine model of hemorrhagic shock to determine its effect on lactic acidosis, serum bicarbonate, $\mathrm{pH}$, and cardiac output. Thirteen dogs were anesthetized, paralyzed, mechanically ventilated and hemodynamically monitored. Hypotension was induced and maintained at a MAP of $40-45 \mathrm{mmHg}$ by controlled hemorrhage and reinfusion. After $2.5 \mathrm{hr}$ of shock, the dogs were randomized in 2 groups: $A=6$ control dogs received $\mathrm{NaCl}$ infusion; $\mathrm{B}=7$ dogs received $\mathrm{NaHCO}_{3} 1$ $\mathrm{mEq} / \mathrm{kg}$ followed by a continuous infusion of 2.5 $\mathrm{mEq} / \mathrm{kg} / \mathrm{hr}$ for $2.5 \mathrm{hr}$.

\begin{tabular}{|c|c|c|c|c|c|}
\hline \multicolumn{2}{|c|}{$\begin{array}{l}\text { VARIABLES } \\
\text { (MEAN } \pm \text { 8D) }\end{array}$} & BASELINE & $\begin{array}{c}\text { HEMORAHAOE } \\
\text { ONLY }\end{array}$ & $\begin{array}{l}\text { HEMORAHACE + } \\
\text { TREATMENT }\end{array}$ & \multirow[b]{2}{*}{ Reculta: } \\
\hline $\mathrm{Cl}$ & A & $4.3 \pm 0.9$ & $1.1 \pm 0.1$ & $1.2 \pm 0.3$ & \\
\hline Cl & B & $4.2 \pm 1.3$ & $1.0 \pm 0.2$ & $1.3 \pm 0.3$ & $=p<0.05$ \\
\hline LACT & A & $0.9 \pm 0.4$ & $6.8 \pm 0.9$ & $5.1 \pm 1.2$ & \\
\hline LACT & $\mathbf{B}$ & $0.7 \pm 0.4$ & $7.1 \pm 3.1$ & $10.1 \pm 3.2$ & \\
\hline $\mathrm{HCO}_{3}^{-}$ & A & $20.1 \pm 1.8$ & $13.4 \pm 1.6$ & $13.6 \pm 2.0$ & \\
\hline $\mathrm{HCO}_{3}^{-}$ & $\mathbf{B}$ & $20.1 \pm 1.8$ & $11.1 \pm 3.0$ & $13.3 \pm 2.3$ & \\
\hline pH & A & $7.34 \pm .03$ & $7.09 \pm .07$ & $7.17 \pm .04$ & \\
\hline pH & B & $7.37 \pm .02$ & $7.03 \pm .10$ & $7.16 \pm .10$ & \\
\hline
\end{tabular}

As in other models of lactic acidosis (hypoxic and phenformin induced), this model demonstrates an increase in lactic acid associated with $\mathrm{NaHCO}_{3}$ administration. Although the pathophysiologic 
mechanism is unclear, it may be related to a decreased intracellular $\mathrm{pH}$ due to diffusion of $\mathrm{CO}_{2}$.

\section{EARTHQUAKE IN MEXICO}

\author{
Claude de Ville de Goyet, M.D., \\ Washington, D.C., U.S.A.
}

The earthquake that rocked Mexico City on 19 September 1985 quickly became an international event. This video reports on the events of the first 10 days after the quake. Starting with the thousands of national volunteers who spontaneously mobilized themselves to search for survivors, we view the devastating destruction to several public sector health institutions and the evacuation of a private sector hospital as a strong aftershock hit the city $\mathbf{3 6}$ hours later. Problems with the water supply, temporary shelter and international assistance are also dealt with, as well as identification of victims and rumors of impending epidemics.

\section{EARTHQUAKE IN EL SALVADOR}

\section{Claude de Ville de Goyet, M.D., Washington, D.C., U.S.A.}

During 1985 and 1986 Latin America suffered three serious earthquakes; in Chile, Mexico and El Salvador. This video discusses the factors that made the earthquake of 10 October 1986 different from the others. These include the quake's direct physical impact on the government's capacity to operate; the conflicting nature of information on its intensity; the serious and long term impact on the delivery of health care; and the competitive atmosphere in which foreign teams operated and international assistance was handled.

\section{VOLCANIC ERUPTION IN ARMERO}

\author{
Claude de Ville de Goyet, M.D., \\ Washington, D.C., U.S.A.
}

After nearly 150 years of lying dormant, the Nevado del Ruiz volcano in Central Colombia erupted on 13 November 1985, leaving in its wake a trail of death and destruction and almost burying completely the town of Armero. An estimated 23,000 persons lost their life in this disaster. Search and rescue activities could only be carried out by helicopter.
This video examines this particular search and rescue effort as well as mass casualty management, triage and other aspects of disaster management.

\section{INTERNATIONAL ASSISTANCE IN DISASTERS}

\author{
Claude de Ville de Goyet, M.D., \\ Washington, D.C., U.S.A.
}

International health relief assistance can alleviate suffering and contribute to more rapid rehabilitation when it is properly directed toward the priority needs of a disaster stricken country. But when it is misguided by unsubstantiated perceptions of what the health needs "ought to be", this assistance exacerbates problems and contributes to chaos.

This video presentation explores the delicate balance that exists between donor and recipient and outlines the positive and negative efforts of international assistance provided by well-intentioned donors on the health care delivery system of disaster-stricken countries.

\section{GELLULAR TELECOMMUNICATIONS AT AMTRAK'S WORST CRASH}

\section{Charles E. Wiles, III, M.D. and Ameen I. Ramzy,} M.D., Baltimore, Maryland, U.S.A.

The worst rail accident in Amtrak history occurred in Chase, MD, USA, on January 4, 1987. Management of the disaster by the Emergency Medical System was nearly perfect. Essential communications both at the scene of the accident and throughout the region were adequately handled by normal public service (fire, police, EMS) radio frequencies following normal operation procedures. Nonessential but desirable information demands threatened to overload standard radio channels. In addition, unfamiliarity with radio discipline by some physicians impeded communications at times. The use of portable and automobile-mounted cellular telephones eliminated these problems and simplified communications from the disaster site to the rest of the region. Cellular telephones were used for 1) Site to trauma center communication. 2) Site to local hospital communications. 3) Two-way communications from the communication center (SYSCOM) to the accident site. 4) Site to fire station communications 